\title{
INFLUÊNCIA DAS CARACTERÍSTICAS SOCIOECONÔMICAS, CAPACIDADE DE GESTÃO E COMPORTAMENTO EMPREENDEDOR NO SUCESSO DOS EMPREENDEDORES PARTICIPANTES DO PROGRAMA DE MICROCRÉDITO DO BANCO PALMAS
}

\author{
Gilberto Barroso da Frota - Universidade de Fortaleza ${ }^{1}$ \\ Marcus Vinicius de Oliveira Brasil - Universidade Federal do Ceará ${ }^{2}$ \\ Raimundo Eduardo Silveira Fontenele - Universidade de Fortaleza ${ }^{3}$
}

Resumo: $O$ objeto em estudo está inserido em um bairro de baixa renda localizado na região metropolitana de Fortaleza denominado de Conjunto Palmeiras, reconhecido popularmente por ser um bairro com grandes conquistas obtidas por meio da Associação de Moradores do Conjunto Palmeiras (ASMOCONP). O presente estudo tem como problemática: Qual a influência do perfil empreendedor, capacidade de gestão e perfil socioeconômico na conquista do sucesso dos microempreendedores? O objetivo geral da pesquisa é avaliar a relação entre comportamento empreendedor, capacidade de gestão, perfil socioeconômico e sucesso das empresas que utilizam a linha de crédito do Banco Palmas. Os objetivos específicos são: caracterizar o perfil dos empreendedores que utilizaram o microcrédito do Banco Palmas quanto ao sexo, idade, nível de escolaridade, estado civil e experiência profissional; identificar a influência dos aspectos socioeconômicos e da capacidade de gestão dos empreendedores; e identificar as características empreendedoras por meio da aplicação do questionário proposto por Carland, Carland e Hoy (1992) aos empreendedores. Para responder à pergunta de pesquisa aplicou-se um questionário de 56 questões com 319 empreendedores. Na tabulação dos dados aplicou-se a análise fatorial confirmatória por meio de Modelo de Equações Estruturais (SEM), utilizando-se dos softwares SPSS versão 20.0 (para AFC) e AMOS 16.0 (para SEM). Como resultados, no que se refere às variáveis submetidas a exame para avaliação de seu impacto no sucesso empresarial, constatou-se não existir relação entre as variáveis comportamento empreendedor e sucesso. No que diz respeito à variável perfil socioeconômico e sucesso obteve-se um índice de regressão de -2,12. Apenas na variável capacidade de gestão e sucesso empresarial pode-se afirmar a existência de correlação de 0,19 . Por fim, indicando caminhos para futuras investigações que possam trazer contribuição ao campo do empreendedorismo, sugere-se comparar os resultados encontrados com outras pesquisas e incluir os impactos provenientes das variáveis exógenas a fim de refinar este estudo.

Palavras-chave: Empreendedorismo; Economia Solidária; Microcrédito.

\footnotetext{
${ }^{1}$ E.mail: gilbertobarroso@hotmail.com - Endereço: Av. Washington Soares, 1321, Edson Queiroz, Fortaleza, CE. CEP 60.811-905.

2 E.mail: mvobrasil@gmail.com

${ }^{3}$ E.mail: fontenele@unifor.br
}

DOI: 10.14211regepe32140. FROTA, G. B.; BRASIL, M. V. O.; FONTENELE, R. E. S. Influência das características socioeconômicas, capacidade de gestão e comportamento empreendedor no sucesso dos empreendedores participantes do programa de microcrédito do Banco Palmas. Revista de Empreendedorismo e Gestão de Pequenas Empresas, v.3, n.2, p. 42-69, 2014. 


\title{
INFLUENCE OF SOCIOECONOMIC CHARACTERISTICS, MANAGEMENT COMPETENCIES AND ENTREPRENEURIAL BEHAVIOR IN SUCCESS OF PROGRAM PARTICIPANTS OF MICRO-CREDIT OF PALMAS BANK
}

\begin{abstract}
The object under study is inserted into a low-income neighborhood in the metropolitan region of Fortaleza called Group of Palmeiras, popularly recognized for being a neighborhood with great achievements obtained through the Association of Residents of Group of Palmeiras (ASMOCONP). The present study has as problematic: What is the influence of the entrepreneurial profile, management capacity and socioeconomic profile to the success of micro-entrepreneurs? The overall objective of the research is to evaluate the relationship between entrepreneurial behavior, management capacity, socioeconomic profile and success of companies that use the line of credit from Palmas Bank. The specific objectives are: to characterize the profile of entrepreneurs who used microcredit of Palmas Bank regarding gender, age, education level, marital status and work experience; identify the influence of socioeconomic factors, and the management capacity of entrepreneurs; and identify the entrepreneurial characteristics by applying the questionnaire proposed by Carland, Carland and Hoy (1992) to the entrepreneurs. To answer the research question we applied a questionnaire with 56 questions to 319 entrepreneurs. In tabulating of the data, it was applied the confirmatory factor analysis using the Model of Structural Equations (SEM), using the SPSS software version 20.0 (to AFC) and AMOS 16.0 (for SEM). As results, with regard to the variables under examination to assess their impact on business success, it was found that does not exist a relationship between the variables entrepreneurial behavior and success. With regard to the variable of socioeconomic profile and success, it was obtained a regression rate of -2.12 . Only in the variable management capacity and business success it can be affirmed the existence of a correlation of 0.19 . Finally, pointing the way to future research that may bring contribution to the field of entrepreneurship, it is suggested to compare the results found with other researches and includes the impacts from the exogenous variables to refine the study.
\end{abstract}

Keywords: Entrepreneurship; Solidarity Economy; Microcredit.

\section{Introdução}

Nos últimos anos, tem-se verificado um aumento de experiências econômicas e sociais fundamentadas nos princípios da autogestão e solidariedade. No Brasil, levantamentos preliminares indicam a ocorrência de mais de 20 mil experiências produtivas que se denominam solidárias (SANTANA JÚNIOR, 2005).

A Economia Solidária, conforme preceitua Singer (2002), possui uma finalidade multidimensional, isto é, envolve as dimensões: social, econômica, política, ecológica e cultural. Isso porque, além da visão econômica de geração de trabalho e renda associada a empreendimentos dessa natureza, as experiências de Economia Solidária se projetam no espaço público no qual estão inseridas, tendo como perspectiva a construção de um ambiente socialmente justo e sustentável.

DOI: 10.14211regepe32140. FROTA, G. B.; BRASIL, M. V. O.; FONTENELE, R. E. S. Influência das características socioeconômicas, capacidade de gestão e comportamento empreendedor no sucesso dos empreendedores participantes do programa de microcrédito do Banco Palmas. Revista de Empreendedorismo e Gestão de Pequenas Empresas, v.3, n.2, p. 42-69, 2014. 
Vale ressaltar que a Economia Solidária não se confunde com o chamado "Terceiro Setor", que substitui o Estado nas suas obrigações legais e inibe a emancipação de trabalhadores enquanto sujeitos de direitos. $O$ incremento desse fenômeno se deve, principalmente, à reação de trabalhadores à crescente exclusão, desemprego urbano e desocupação rural, resultantes, muitas vezes, da expansão agressiva de uma globalização que torna mais e mais pessoas dispensáveis ou desqualificadas para ocupar um local no mercado de trabalho.

Dessa forma, surgem cada vez mais novos empreendedores impulsionados pela necessidade de sobrevivência, de concretização de uma ideia ou simplesmente pelo desejo de se tornarem donos do próprio negócio. De acordo com o Serviço Brasileiro de Apoio às Micro e Pequenas Empresas (SEBRAE, 2006), o último censo do comércio de Fortaleza identificou que $56,60 \%$ dos estabelecimentos são informais, não possuem Cadastro Nacional da Pessoa Jurídica (CNPJ) e/ou Inscrição Municipal na Prefeitura de Fortaleza e não são registrados na Junta Comercial do Estado.

No entanto, para se abrir um negócio existe a necessidade inicial de investimento. A falta de recursos obriga o empreendedor a procurar uma instituição financeira, porém, as pessoas menos favorecidas não possuem as garantias exigidas pelos bancos, inviabilizando, dessa forma, a concessão de crédito. Nesse cenário, os bancos comunitários e os programas de microcrédito surgem como alternativas aos desprovidos. Importante dizer que os programas de microcrédito são considerados instrumentos para se reduzir a pobreza (YUNUS; JOLIS, 2000).

Posta assim a questão, o objeto em estudo está inserido em um bairro de baixa renda localizado na região metropolitana de Fortaleza, denominado de Conjunto Palmeiras. É reconhecido popularmente por ser um bairro com grandes conquistas obtidas por meio da Associação de Moradores do Conjunto Palmeiras (ASMOCONP). Diante do exposto, pretende-se responder à seguinte questão da pesquisa: Qual a influência do perfil empreendedor, capacidade de gestão e perfil socioeconômico na conquista do sucesso dos empreendedores?

Sendo assim, o objetivo geral da presente pesquisa é avaliar a relação entre comportamento empreendedor, capacidade de gestão, perfil socioeconômico e

DOI: 10.14211regepe32140. FROTA, G. B.; BRASIL, M. V. O.; FONTENELE, R. E.

S. Influência das características socioeconômicas, capacidade de gestão e comportamento empreendedor no sucesso dos empreendedores participantes do programa de microcrédito do Banco Palmas. Revista de Empreendedorismo e Gestão de Pequenas Empresas, v.3, n.2, p. 42-69, 2014. 
sucesso das empresas que utilizam a linha de crédito do Banco Palmas. Os objetivos específicos são: a) caracterizar o perfil dos empreendedores que utilizaram o microcrédito do Banco Palmas quanto ao sexo, idade, nível de escolaridade, estado civil e experiência profissional; b) identificar a influência dos aspectos socioeconômicos e da capacidade de gestão dos empreendedores; e c) identificar as características empreendedoras por meio da aplicação do questionário proposto por Carland, Carland e Hoy (1992) aos empreendedores.

A pesquisa se torna relevante devido ao aumento de experiências econômicas e sociais fundamentadas nos princípios da autogestão e solidariedade. Disso deriva a necessidade de se investigar a formação desses empreendedores, ou seja, de identificar e desenvolver as características empreendedoras ou conscientizar os indivíduos da importância da existência de tais características para se criar um empreendimento.

\section{Empreendedorismo}

A origem da prática empreendedora está intimamente conectada ao surgimento da arte da negociação. Com a evolução da humanidade ao longo do tempo, surgiram inovações e novas necessidades criadas a partir de ideias consideradas, para a época, impossíveis de serem realizadas. Existem várias pesquisas que abordam o tema de como se traçar o perfil empreendedor de empresários e gerentes. No entanto, alguns autores entendem que não há ainda um perfil psicológico absolutamente científico (CARLAND; CARLAND, 1996, FILION, 1999, VEIT; GONÇALVES FILHO, 2007).

O termo empreendedorismo possui diferentes definições produzidas por diversos autores. De acordo com Bygrave e Hofer (1991), os pesquisadores do empreendedorismo encontram dificuldades pela falta de uma estrutura conceitual comum para empreender o negócio. Conforme o dicionário Houaiss, empreendedorismo é disposição ou capacidade de idealizar, coordenar e realizar projetos, serviços e negócios.

DOI: 10.14211regepe32140. FROTA, G. B.; BRASIL, M. V. O.; FONTENELE, R. E. S. Influência das características socioeconômicas, capacidade de gestão e comportamento empreendedor no sucesso dos empreendedores participantes do programa de microcrédito do Banco Palmas. Revista de Empreendedorismo e Gestão de Pequenas Empresas, v.3, n.2, p. 42-69, 2014. 
Já segundo Hisrich e Peters (2009), o desenvolvimento da teoria do empreendedorismo aconteceu ao longo dos séculos. O Quadro 1 sintetiza o desenvolvimento da teoria do empreendedorismo da seguinte forma:

\begin{tabular}{|c|l|}
\hline Idade Média & $\begin{array}{l}\text { Era um grupo de guerreiros em ação e um indivíduo que administrava projeto de } \\
\text { produção em larga escala. O empreendedor começa a gerenciar grandes projetos } \\
\text { de produção com ajuda governamental, deixando de assumir os riscos. }\end{array}$ \\
\hline Século XVII & $\begin{array}{l}\text { Indivíduo voltado para ter lucro na fixação de um preço num contrato com o } \\
\text { governo. }\end{array}$ \\
\hline 1725 & $\begin{array}{l}\text { Richard Cantillon - escritor e economista francês, o define como o indivíduo que } \\
\text { assumia riscos, planejando, supervisionando e organizando. }\end{array}$ \\
\hline 1803 & $\begin{array}{l}\text { Jean-Baptist Say - por seu turno, separa os lucros do empreendedor do } \\
\text { capitalista. }\end{array}$ \\
\hline 1876 & $\begin{array}{l}\text { Francis Wlater - estabelece distinção entre os que fornecem fundos e recebem } \\
\text { lucros gerados por sua capacidade gerencial. }\end{array}$ \\
\hline 1934 & $\begin{array}{l}\text { Joseph Schumpeter - entende que empreendedor é um inovador e estabelece } \\
\text { tecnologia inédita. }\end{array}$ \\
\hline 1961 & $\begin{array}{l}\text { David McClelland - visualiza o empreendedor como um tomador de risco } \\
\text { moderado. }\end{array}$ \\
\hline 1964 & Peter Drucker - vislumbra-o como alguém que maximiza oportunidades. \\
\hline 1976 & $\begin{array}{l}\text { Albert Shapero - o empreendedor toma iniciativa, organiza mecanismos } \\
\text { socioeconômicos e aceita riscos de fracasso. }\end{array}$ \\
\hline 1983 & $\begin{array}{l}\text { Karl Vesper - enxerga os empreendedores como diversos economistas, } \\
\text { engenheiros, gestores e políticos. }\end{array}$ \\
\hline 1985 & $\begin{array}{l}\text { Gifford Pinchot - alude ao entrepreuner como um empreendedor dentro de uma } \\
\text { organização já estabelecida. }\end{array}$ \\
\hline $\begin{array}{l}\text { Robert Hisrich - o empreendedorismo é o processo de criar algo diferente e com } \\
\text { valor, para o qual o empreendedor dedica o tempo e os esforços necessários, } \\
\text { assume os riscos financeiros, psicológicos e sociais correspondentes e recebe as } \\
\text { consequentes recompensas da satisfação econômica e pessoal. }\end{array}$ \\
\hline
\end{tabular}

QUADRO 1 - Desenvolvimento da Teoria do Empreendedorismo

Fonte: Adaptado de Hisrich e Peters (2009).

De acordo com Drucker (2011), o trabalho específico do empreendedor é tornar o negócio de hoje capaz de construir o futuro, de converter-se em um negócio diferente. Com o aproveitamento de novas oportunidades nos negócios, o empreendedor está sempre relacionado à criação de uma nova forma de uso do emprego tradicional a partir de novas combinações.

O empreendedor busca a autorrealização e o desenvolvimento local, o que leva, consequentemente, ao desenvolvimento de seu entorno. Essas intenções são as mesmas encontradas, em grande parte, nos empresários que utilizam o microcrédito do Banco Palmas. A atitude de motivação frente às dificuldades encontradas no decorrer da caminhada empresarial engrandece o ser humano, DOI: 10.14211regepe32140. FROTA, G. B.; BRASIL, M. V. O.; FONTENELE, R. E. S. Influência das características socioeconômicas, capacidade de gestão e comportamento empreendedor no sucesso dos empreendedores participantes do programa de microcrédito do Banco Palmas. Revista de Empreendedorismo e Gestão de Pequenas Empresas, v.3, n.2, p. 42-69, 2014. 
gerando autoestima não só para si, mas para todos os que estão ao seu redor, tornando a comunidade cada vez mais forte.

\section{Economia Solidária}

O termo Economia Solidária foi criado pelos operários nos primórdios do capitalismo industrial como resposta à pobreza e ao desemprego resultante da difusão desregulada das máquinas-ferramentas e do motor a vapor no início do século XIX. No Brasil, essa economia surge como resposta à grande crise de 1981 1983, quando muitas indústrias, inclusive de grande porte, pedem concordata e entram em processo falimentar (SINGER, 2002).

Os estudos sobre Economia Solidária, de acordo com Santos (2010), iniciaram-se no Brasil por um grupo de pesquisadores da Faculdade de Filosofia e Ciências da Universidade Estadual Paulista "Júlio de Mesquita Filho" (UNESP), em 1996. Esse grupo de pesquisa se autodenominava "Organizações e Democracia", e foi coordenado por Cândido Vieitez e Neusa Dal Ri. Esses estudos acerca desse tipo de economia se iniciaram após a realização do I e II Simpósio Nacional Universidade-Empresa nos anos de 1996 e 1998, respectivamente.

A partir de então, projetos de pesquisas em âmbito nacional começam a serem elaborados. As pesquisas começam a se intensificar, as experiências práticas passam a ser partilhadas e o movimento ganha mais força e divulgação. Em 1998, cansados de conviver com desigualdades sociais gritantes, abismos excludentes gerados pela concentração de renda e a falta de programas governamentais eficientes que assolam grande parte da população, o Banco Palmas é inaugurado.

Empreendimentos de Economia Solidária, conforme define Gonçalves (2005), são sociedades que desempenham atividades econômicas e cuja gestão é exercida democraticamente pelos trabalhadores que delas participam. Os empreendimentos de Economia Solidária podem ser divididos em empreendimentos de autogestão e empresas de autogestão.

Os empreendimentos autogestionários se caracterizam por serem aqueles constituídos por meio de projetos sociais realizados em comunidades periféricas,

DOI: 10.14211regepe32140. FROTA, G. B.; BRASIL, M. V. O.; FONTENELE, R. E. S. Influência das características socioeconômicas, capacidade de gestão e comportamento empreendedor no sucesso dos empreendedores participantes do programa de microcrédito do Banco Palmas. Revista de Empreendedorismo e Gestão de Pequenas Empresas, v.3, n.2, p. 42-69, 2014. 
não sendo resultado de uma atividade econômica anterior, como é o caso das empresas de autogestão, tendo como exemplo, o Banco Palmas. Lisboa (1999) retrata que a missão da economia solidária consiste em possibilitar a construção de uma nova sociedade em longo prazo, porém, no aqui e agora.

Já as empresas de autogestão são as que surgem de um negócio anterior fracassado. Isso implica dizer que já havia uma atividade econômica organizada, que passa a ser dirigida pelos colaboradores que já eram integrantes como empregados celetistas.

Para Gonçalves (2005) ainda se está muito longe da normatização de um estatuto dos empreendimentos de Economia Solidária. No entanto, se aceita que empreendimentos de Economia Solidária sejam sociedades cooperativas. As atuais formas jurídicas segundo as quais os empreendimentos de Economia Solidária e as empresas de autogestão se organizam juridicamente estão previstas no Código Civil, Lei no 10.406, de 10 de janeiro de 2002, e em leis especiais.

De acordo com Yunus e Jolis (2000), abrir saídas para o trabalho independente criando instituições apropriadas e adotando medidas eficazes seria a melhor estratégia para eliminar o desemprego e a pobreza. Dentre as opções buscadas para superar a exclusão social encontra-se a Economia Solidária. Singer (2002) usa o termo Economia Solidária referindo-se a um modo de produção e distribuição alternativo ao capitalismo, criado e recriado periodicamente pelos que se encontram (ou temem ficar) marginalizados no mercado de trabalho.

Essa economia caracteriza-se por ser um jeito de fazer a economia de produção, oferta de serviços, comercialização, finanças ou consumo com base na democracia e na cooperação, o que pode ser chamado de autogestão. Na Economia Solidária não existem patrão nem empregados. Todos os integrantes do empreendimento (associação, cooperativa) são, ao mesmo tempo, trabalhadores e donos.

O desenvolvimento de uma Economia Solidária obriga o enfrentamento de pelos menos três grandes desafios: a superação das heranças românticas do socialismo utópico; seu caráter não capitalista, mas subordinado ao capitalismo; e seu peso relativo enquanto bloco econômico (BERTUCCI; SILVA, 2003).

DOI: 10.14211regepe32140. FROTA, G. B.; BRASIL, M. V. O.; FONTENELE, R. E. S. Influência das características socioeconômicas, capacidade de gestão e comportamento empreendedor no sucesso dos empreendedores participantes do programa de microcrédito do Banco Palmas. Revista de Empreendedorismo e Gestão de Pequenas Empresas, v.3, n.2, p. 42-69, 2014. 
Singer e Souza (2000) descrevem a Economia Solidária como um movimento autogestionário espontâneo da classe trabalhadora. O mais difícil não é, provavelmente, encontrar uma fórmula organizacional ideal, mas mobilizar a grande massa de inativos e marginalizados para que se disponha a empreender.

Conforme elucida Arruda (2005) sobre o processo de mudança de valores e de transformação do mundo, na Economia Solidária, o parâmetro de crescimento econômico ilimitado como razão de ser da atividade econômica cede lugar ao conceito complexo de riqueza como o conjunto de bens materiais e imateriais que servem de base para o desenvolvimento humano e social.

Mance (2003) entende a Economia Solidária como responsável pelo desenvolvimento de redes e da expansão do fluxo de informação. Desta forma, é importante compreender que consumo solidário não significa comprar para ajudar, mas sim, comprar produtos bons, fabricados dentro de certas normas de economia solidária (MANCE, 2003).

\section{Procedimentos metodológicos}

A presente pesquisa foi descritiva e explicativa. Descritiva ao buscar identificar o perfil do empreendedor que utilizou o microcrédito do Banco Palmas e explicativa, com o intuito de compreender os fatores que motivaram esses empreendedores a constituírem seus negócios.

No estudo, foi adotada a técnica de amostragem por conveniência, não probabilístico. De acordo com Cooper e Schindler (2003), na amostra por conveniência, os pesquisadores têm liberdade para escolher quem fará parte da amostra. Malhotra (2006) corrobora o assunto afirmando que este método tem como principais vantagens o custo e o tempo envolvidos devido ao fácil acesso aos entrevistados.

Após a seleção dos empresários que participaram desta pesquisa, aplicouse um questionário estruturado a fim de se obter os dados necessários para extrair as informações precisas para este estudo. O Quadro 2 abaixo identifica as questões utilizadas em cada constructo:

DOI: 10.14211regepe32140. FROTA, G. B.; BRASIL, M. V. O.; FONTENELE, R. E. S. Influência das características socioeconômicas, capacidade de gestão e comportamento empreendedor no sucesso dos empreendedores participantes do programa de microcrédito do Banco Palmas. Revista de Empreendedorismo e Gestão de Pequenas Empresas, v.3, n.2, p. 42-69, 2014. 


\begin{tabular}{|c|c|c|c|}
\hline CONSTRUCTO & QUESTÕES & BASE TEÓRICA & ITENS \\
\hline $\begin{array}{c}\text { Perfil } \\
\text { Socioeconômico }\end{array}$ & $1,2,3,6,15$ & $\begin{array}{l}\text { Lenhard (1985), } \\
\text { Sheth, Banwari, Bruce } \\
\text { (2001), } \\
\text { Matthews e Moser (1996), } \\
\text { Castells (1999), } \\
\text { Rocha (2008), } \\
\text { Grundstén (2004). }\end{array}$ & $\begin{array}{c}\text { Traçar o Perfil socioeconômico } \\
\text { do entrevistado para analisar a } \\
\text { influência no sucesso } \\
\text { empresarial. }\end{array}$ \\
\hline $\begin{array}{l}\text { Capacidade } \\
\text { de } \\
\text { Gestão }\end{array}$ & $\begin{array}{c}4,5,7,8,11 \\
12,13,17 \\
18,19,20 \\
21,22,23\end{array}$ & $\begin{array}{l}\text { Fischer (2001), } \\
\text { Fleck (2009), } \\
\text { Mintzberg, Ahlstrand e } \\
\text { Lampel (2000), } \\
\text { Prahalad \& Hamel (1990), } \\
\text { Fleury (1999). }\end{array}$ & $\begin{array}{c}\text { Identificar a capacidade de } \\
\text { gestão do entrevistado a partir } \\
\text { dos conhecimentos adquiridos } \\
\text { pela vivência profissional, } \\
\text { participação de cursos e } \\
\text { treinamentos somados a } \\
\text { programas gerenciais que } \\
\text { auxiliam na gestão do } \\
\text { empreendimento para analisar a } \\
\text { influência no sucesso } \\
\text { empresarial. }\end{array}$ \\
\hline $\begin{array}{l}\text { Comportamento } \\
\text { Empreendedor }\end{array}$ & $\begin{array}{c}\text { Parte II } \\
24.1 \text { a } 24.33\end{array}$ & $\begin{array}{l}\text { McClelland (1972), } \\
\text { Cooley (1990), } \\
\text { Degen (1989), } \\
\text { Mischel (1973), } \\
\text { Carland e Carland (1996), } \\
\text { Gonçalves (2005), } \\
\text { Gimenez, Inácio Jr. e Sunsin, } \\
\text { (2001) }\end{array}$ & $\begin{array}{c}\text { Identificar e classificar as } \\
\text { características comportamentais } \\
\text { empreendedoras para analisar a } \\
\text { influência no sucesso } \\
\text { empresarial. }\end{array}$ \\
\hline $\begin{array}{c}\text { Sucesso } \\
\text { Empresarial }\end{array}$ & 14 e 16 & $\begin{array}{l}\text { Tedeschi e Kilmer (2005), } \\
\text { Alvarez e Barney (2004), } \\
\text { Whetten (1980), } \\
\text { Fritz (1996). }\end{array}$ & $\begin{array}{c}\text { Verificar o tempo de } \\
\text { funcionamento da empresa, o } \\
\text { faturamento e as influências do } \\
\text { perfil socioeconômico, } \\
\text { capacidade de gestão e } \\
\text { comportamento empreendedor } \\
\text { para alcançar o sucesso. }\end{array}$ \\
\hline
\end{tabular}

QUADRO 2 - Constructos e respectiva base teórica

Fonte: Os Autores (2012).

No tratamento dos dados da pesquisa, observam-se passos importantes para o processo de análise, tais como o estabelecimento de categorias, a identificação das características, a pesquisa das intenções e das percepções, o que permitiu conhecer toda a problemática envolvida nas relações estudadas.

$\mathrm{Na}$ falta de um consenso sobre o instrumento para mensurar o perfil empreendedor, optou-se por utilizar o questionário Carland Entrepreneurship Index (CEI), desenvolvido em 1992 por Carland, Carland e Hoy e aperfeiçoado por Carland e Carland em 1996. Optou-se por este questionário por reunir conceitos de diversos

DOI: 10.14211regepe32140. FROTA, G. B.; BRASIL, M. V. O.; FONTENELE, R. E. S. Influência das características socioeconômicas, capacidade de gestão e comportamento empreendedor no sucesso dos empreendedores participantes do programa de microcrédito do Banco Palmas. Revista de Empreendedorismo e Gestão de Pequenas Empresas, v.3, n.2, p. 42-69, 2014. 
especialistas e importantes pesquisadores, contribuindo para um melhor entendimento do complexo fenômeno do empreendedorismo e utilizando a psicologia, a economia e as ciências sociais.

O CEI consiste em um questionário de autorrespostas com 33 pares de afirmações, sendo obrigatório ao respondente escolher uma das afirmações em cada par. Numericamente, a escala que define o CEI procura detectar a maior ou menor presença desses elementos em um indivíduo, colocando-o em um intervalo de variação de 0 (mais baixo) a 33 (mais alto) pontos. Para dar conteúdo semântico a esses valores, tem sido comum agregá-los em três faixas: de (a) Microempreendedor (de 0 a 15 pontos) a (c) Macroempreendedor (de 26 a 33 pontos), passando pela faixa intermediária (b) Empreendedor (de 16 a 25 pontos) (INÁCIO JÚNIOR; GIMENEZ, 2004).

O tratamento quantitativo consistiu na aplicação da análise fatorial confirmatória por meio do Modelo de Equações Estruturais (SEM), utilizando-se dos softwares SPSS (para AFC) e AMOS (para SEM). De acordo com Zeller e Carmines (1980), a análise fatorial é relacionada para tornar os dados observados de forma mais fácil de serem interpretados.

A Modelagem de Equações Estruturais (SEM, do inglês Structural Equation Modeling) é composta por várias técnicas. Dentre elas, a análise de caminhos, a análise de estrutura de covariância, a análise de variáveis latentes e a análise fatorial confirmatória. A SEM permite a possibilidade de se considerar variáveis observadas com erro de medição e variáveis não observadas ou latentes: variáveis teóricas que só podem ser estimadas indiretamente por meio de variáveis observadas (HAIR JR. et al., 2009).

Os dados foram coletados entre dezembro de 2011 e fevereiro de 2012 de uma amostra de 319 empreendedores, localizados na região metropolitana de Fortaleza. Os instrumentos de coleta foram entregues diretamente aos sujeitos da pesquisa e preenchidos de imediato ao lado dos pesquisadores para elucidar qualquer dúvida sobre o questionário.

DOI: 10.14211regepe32140. FROTA, G. B.; BRASIL, M. V. O.; FONTENELE, R. E. S. Influência das características socioeconômicas, capacidade de gestão e comportamento empreendedor no sucesso dos empreendedores participantes do programa de microcrédito do Banco Palmas. Revista de Empreendedorismo e Gestão de Pequenas Empresas, v.3, n.2, p. 42-69, 2014. 
Análise dos resultados

Nesta etapa da pesquisa, realizou-se a análise descritiva para se investigar a exatidão da entrada dos dados, a frequência e distribuição dos casos omissos e a distribuição das variáveis. Os dados inseridos foram conferidos e não apresentaram erros de digitação. Os dados omissos apresentados não representaram $3 \%$ em qualquer variável. Os resultados da pesquisa estão distribuídos em três etapas a seguir.

A primeira parte do questionário aplicada aos indivíduos da pesquisa abordou os aspectos socioeconômicos, a capacidade de gestão e o sucesso empresarial, procurando traçar um perfil a partir da análise descritiva.

Após o último censo realizado no ano de 2010 (IBGE, 2011), o Conjunto Palmeiras tem 39.599 habitantes, sendo 18.792 do sexo feminino, o que representa $51,35 \%$ da população total do bairro. Já $48,65 \%$ são do sexo masculino, isto é, 17.807 habitantes. O Conjunto Palmeiras é o quarto bairro mais populoso, ficando atrás somente de Messejana com 41.689 habitantes, Jangurussu com 50.479 habitantes e Passaré com 50.940 habitantes.

$\mathrm{Na}$ Tabela 1 pode-se identificar a quantidade de empreendedores por gênero:

TABELA 1 - Empreendedores Segundo Gênero

\begin{tabular}{c|c|c}
\hline GÉNERO & FREQUÊNCIA & $\%$ \\
\hline Masculino & 69 & 21,6 \\
Feminino & 250 & 78,4 \\
TOTAL & 100 & 100 \\
\hline
\end{tabular}

Fonte: Os Autores (2012).

Após a tabulação dos dados, pode-se afirmar que $78 \%$ dos empreendedores são do sexo feminino. Isto se deve ao fato de existirem diversos programas promovidos pela ASMOCONP como, por exemplo, o Projeto Elas que tem o intuito de possibilitar a geração de renda para mulheres que procuram a associação para a capacitação.

DOI: 10.14211regepe32140. FROTA, G. B.; BRASIL, M. V. O.; FONTENELE, R. E.

S. Influência das características socioeconômicas, capacidade de gestão e comportamento empreendedor no sucesso dos empreendedores participantes do programa de microcrédito do Banco Palmas. Revista de Empreendedorismo e Gestão de Pequenas Empresas, v.3, n.2, p. 42-69, 2014. 
Neri (2008) observa que nas avaliações de microcrédito realizadas na América Latina, as mulheres são as verdadeiras protagonistas, ou seja, são elas quem comandam os negócios. Importa mencionar que $62 \%$ da clientela do Crediamigo são mulheres, enquanto os homens totalizam apenas 38\%. Ao contrário, o censo realizado pelo SEBRAE em parceria com a Fecomércio demonstra que $54,15 \%$ dos microempresários são do sexo masculino, contra $45,85 \%$ do sexo feminino (SOUZA, 2010).

Quanto ao estado civil dos empreendedores, a Tabela 2 identifica os entrevistados na pesquisa:

TABELA 2 - Estado Civil dos Empreendedores

\begin{tabular}{c|c|c}
\hline ESTADO CIVIL & FREQUÉNCIA & $\%$ \\
\hline Solteiro & 72 & 22,6 \\
Casado & 226 & 70,8 \\
Separado & 21 & 6,6 \\
TOTAL & 319 & 100 \\
\hline
\end{tabular}

Fonte: Os Autores (2012).

Observa-se maior frequência para os empreendedores casados, com 226 indivíduos, representando 70,8\%. Em segundo, encontram-se os solteiros, com 72 pessoas, representando $22,6 \%$ e em terceiro, os separados, com 21 indivíduos, representando 6,6\%. Resultado similar pode-se constatar no estudo de Kornijezuk (2004) que encontrou $66,9 \%$ para os casados, $23,1 \%$ para os solteiros e $20,1 \%$ para os separados.

A Tabela 3 abaixo identifica o nível de escolaridade dos empreendedores entrevistados por gênero:

TABELA 3: Escolaridade dos Empresários por Gênero

\begin{tabular}{c|c|c|c|c|c|c|c}
\hline Gênero & $\begin{array}{c}\text { Ensino Fund. } \\
\text { Incompleto }\end{array}$ & $\begin{array}{c}\text { Ensino } \\
\text { Fund. } \\
\text { Completo }\end{array}$ & $\begin{array}{c}\text { Ensino } \\
\text { Médio } \\
\text { Incompleto }\end{array}$ & $\begin{array}{c}\text { Ensino } \\
\text { Médio } \\
\text { Completo }\end{array}$ & $\begin{array}{c}\text { Ensino } \\
\text { Super. } \\
\text { Incompleto }\end{array}$ & $\begin{array}{c}\text { Ensino } \\
\text { Super. } \\
\text { Completo }\end{array}$ & $\begin{array}{c}\text { Pós- } \\
\text { Gradu } \\
\text { ação }\end{array}$ \\
\hline Masculino & 30 & 9 & 10 & 20 & 0 & 0 & 0 \\
Feminino & 92 & 38 & 34 & 81 & 2 & 3 & 0 \\
Total & 122 & 47 & 44 & 101 & 2 & 3 & 0 \\
\hline
\end{tabular}

Fonte: Os Autores (2012).

De acordo com os dados do censo demográfico do IBGE do ano de 2010 (IBGE, 2011), no Brasil, 50,2\% da população com mais de 10 (dez) anos de idade DOI: 10.14211regepe32140. FROTA, G. B.; BRASIL, M. V. O.; FONTENELE, R. E. S. Influência das características socioeconômicas, capacidade de gestão e comportamento empreendedor no sucesso dos empreendedores participantes do programa de microcrédito do Banco Palmas. Revista de Empreendedorismo e Gestão de Pequenas Empresas, v.3, n.2, p. 42-69, 2014. 
nunca frequentou a escola ou não concluiu o Ensino Fundamental. No estado do Ceará, esse número sobe para 55,8\%. Mesmo com resultado inferior ao do resto do País, Ceará atingiu o menor índice se comparado à região Nordeste, que obteve $59 \%$.

$\mathrm{Na}$ pesquisa, foram identificados 122 entrevistados com Ensino Fundamental Incompleto (EFI), o que representa 38,2\% da amostra, sendo o índice de maior percentual identificado no quadro escolaridade por gênero, corroborando o resultado encontrado pelo IBGE, que também obteve maior índice.

Quando se identificam os entrevistados que possuem o Ensino Fundamental Completo (EFC) somando-os aos que possuem Ensino Médio Incompleto (EMI) encontram-se 91 pessoas, o que representa 28,5\% da amostra selecionada. Portanto, percentual bem acima da média da Região Nordeste que é de 15,3\%, do Brasil com 17,4\%, e do estado do Ceará com 17,5\%.

Os entrevistados que possuem Ensino Médio Completo (EMC) e Superior Incompleto $(\mathrm{SI})$ totalizam 103 pessoas, representando 32,9\% da amostra. Este resultado é semelhante ao encontrado no censo do IBGE no ano de 2010, o qual demonstrou que na Região Nordeste obteve-se 20,3\%, no Estado do Ceará, 21,3\%, e no Brasil, 23,5\%, categoria de nível de instrução com a segunda maior incidência percentual (IBGE, 2011).

Com menor incidência percentual na pesquisa (0,9\%), tem-se o nível superior, também identificado no censo com os menores percentuais: $4,9 \%$ na Região Nordeste, 5\% no estado do Ceará e 8,3\% no Brasil. Ressalta-se que é uma conquista identificar pessoas que estão cursando nível superior ou que já o concluíram numa população que tem acesso ao Ensino Superior dificultado.

O próximo item a ser analisado diz respeito a realização de planejamento estratégico para a implementação do negócio. A Tabela 4 abaixo demonstra se existiu ou não esse planejamento:

TABELA 4 - Realização de Planejamento Estratégico

\begin{tabular}{lcc}
\hline \multicolumn{1}{c}{ PLANEJAMENTO ESTRATÉGICO } & FREQUÉNCIA & $\%$ \\
\hline Não tem & 191 & 60,0 \\
Tem vontade, mas nunca realizou & 59 & 18,5 \\
Está em processo de elaboração & 42 & 13,1
\end{tabular}

DOI: 10.14211regepe32140. FROTA, G. B.; BRASIL, M. V. O.; FONTENELE, R. E.

S. Influência das características socioeconômicas, capacidade de gestão e comportamento empreendedor no sucesso dos empreendedores participantes do programa de microcrédito do Banco Palmas. Revista de Empreendedorismo e Gestão de Pequenas Empresas, v.3, n.2, p. 42-69, 2014. 
Foi elaborado nos últimos anos

$\frac{\text { TOTAL }}{\text { Fonte: Os Autores (2012). }}$

8,4 100

Pode-se identificar que $60 \%$ das empresas não realizaram nenhum planejamento estratégico antes de se estabelecerem como um negócio no mercado. E se forem somados os $18,5 \%$ dos empresários que têm intenção de elaborar um planejamento mas ainda não o fizeram, o percentual sobre para $78,5 \%$.

É bem verdade que a ausência de planejamento estratégico compromete a sobrevivência do negócio nos anos mais difíceis da empresa, que são justamente os primeiros anos de atividade, nos quais existe um alto índice de encerramento do negócio. No estudo realizado por Filiardi (2006) encontrou-se um percentual de $81 \%$ de empresários que não realizaram nenhum planejamento antes de iniciar suas atividades.

A segunda parte do questionário aplicado aos indivíduos da pesquisa referese ao perfil empreendedor e às características dos traços de personalidade. Após a tabulação realizada, pode-se identificar a distribuição da amostra quanto à sua pontuação geral.

Dessa forma, utilizando-se dos parâmetros desenvolvido por Carland e Carland (1996), obteve-se a classificação dos entrevistados como: microempreendedor, empreendedor ou macroempreendedor.

No Gráfico 1 está identificada a distribuição de pontos da amostra na escala CEl:

DOI: 10.14211 regepe32140. FROTA, G. B.; BRASIL, M. V. O.; FONTENELE, R. E. S. Influência das características socioeconômicas, capacidade de gestão e comportamento empreendedor no sucesso dos empreendedores participantes do programa de microcrédito do Banco Palmas. Revista de Empreendedorismo e Gestão de Pequenas Empresas, v.3, n.2, p. 42-69, 2014. 


\section{A Revista da ANEGEPE

\section{Histograma}

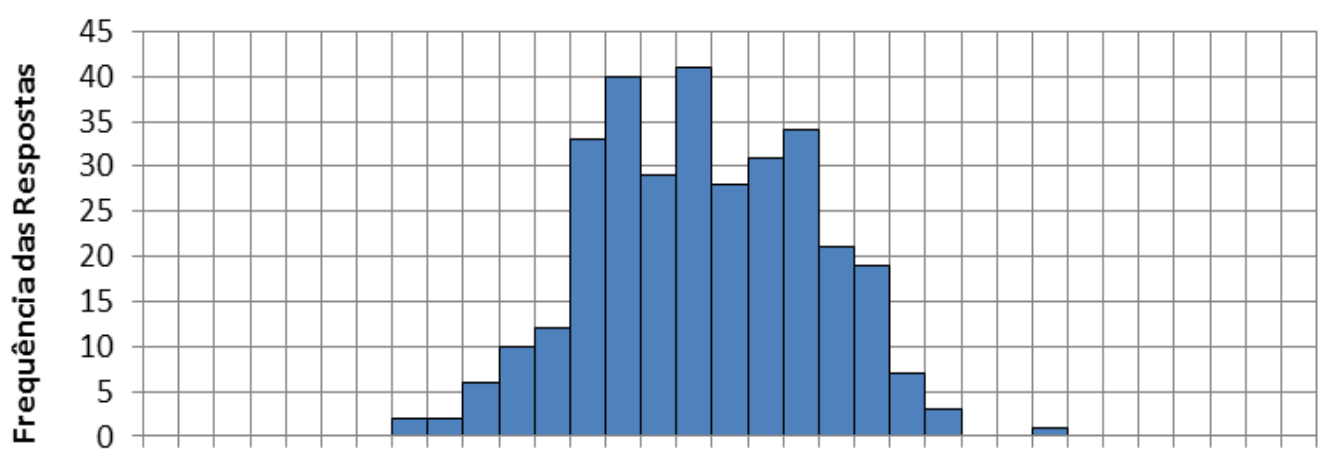

123456789101112131415161718192021222324252627282930313233

Total de pontos no questionário CEI

GRÁFICO 1 - Distribuição de Pontos da Amostra na Escala CEI

Fonte: Os Autores (2012).

Como pontuação máxima da pesquisa, obteve-se 1 (um) entrevistado perfazendo 26 pontos. Com pontuação mínima, houve 2 entrevistados perfazendo 8 pontos. Nesse sentido, ratificando a teoria, não existiu nenhum entrevistado com pontuação menor que 7 .

Do total de entrevistados, identificou-se 1 (um) classificado como macroempreendedor, representando $0,3 \%$ da amostra, 184 classificados como empreendedores, representando 57,8\% da amostra e 134 classificados como microempreendedores, representando $41,9 \%$ da amostra. Comparando-se os resultados obtidos com os de outros estudos (INÁCIO JR., 2002; KORNIJEZUK, 2004; FERREIRA, 2005), identificou-se similaridade quanto à classificação, obtendo maior percentual o empreendedor, em seguida o microempreendedor $\mathrm{e} o$ macroempreendedor em menor percentual.

Dos $41,9 \%$ entrevistados classificados como microempreendedores, $31,9 \%$ atingiram entre 13 e 15 pontos, ficando, portanto, bem próximos da classificação de empreendedor. De maneira semelhante, os $57,8 \%$ entrevistados classificados como empreendedores, 31,4\% conseguiram entre 16 e 18 pontos, ficando bem próximos de serem classificados como microempreendedores.

DOI: 10.14211regepe32140. FROTA, G. B.; BRASIL, M. V. O.; FONTENELE, R. E. S. Influência das características socioeconômicas, capacidade de gestão e comportamento empreendedor no sucesso dos empreendedores participantes do programa de microcrédito do Banco Palmas. Revista de Empreendedorismo e Gestão de Pequenas Empresas, v.3, n.2, p. 42-69, 2014. 
O resultado demonstrado nas Tabelas 5, 6, 7 e 8 apresenta as características empreendedoras obtidas com base nas respostas do questionário CEI, conforme classificação do conceito de Carland e Carland (1996):

TABELA 5 - Resultados CEI Quanto à Característica Traços de Personalidade

\begin{tabular}{c|c|c|c|c|c}
\hline CARACTERISTICAS & QUESTÃO & RCE & RCE\% & RSE & RSE $\%$ \\
\hline Traços de personalidade & 29 & 230 & 72,1 & 89 & 27,9 \\
Traços de personalidade & 10 & 210 & 65,8 & 109 & 34,2 \\
Traços de personalidade & 16 & 186 & 58,3 & 133 & 41,7 \\
Traços de personalidade & 7 & 178 & 55,8 & 141 & 44,2 \\
Traços de personalidade & 32 & 165 & 51,7 & 154 & 48,3 \\
Traços de personalidade & 2 & 144 & 45,1 & 175 & 54,9 \\
Traços de personalidade & 13 & 98 & 30,7 & 221 & 69,3 \\
Traços de personalidade & 6 & 68 & 21,3 & 251 & 78,7 \\
Traços de personalidade & 14 & 64 & 20,1 & 255 & 79,9 \\
Traços de personalidade & 15 & 57 & 17,9 & 262 & 82,1 \\
Traços de personalidade & 18 & 55 & 17,2 & 264 & 82,8 \\
Traços de personalidade & 3 & 50 & 15,7 & 269 & 84,3 \\
\hline
\end{tabular}

Fonte: Os Autores (2012).

$\mathrm{RCE}=$ Resposta Com Característica Empreendedora

$\mathrm{RSE}=$ Resposta Sem Característica Empreendedora

$\%$ RCE = Porcentagem da amostra que marcou a sentença identificada como empreendedora

$\%$ RSE = Porcentagem da amostra que marcou a sentença identificada como não empreendedora

Observa-se na característica traços de personalidade, composta por 12 questões, a menor incidência de respostas identificando como características empreendedoras as da questão 3, que trata sobre Eu nunca terei certeza se este negócio dará certo ou não, representando $15,7 \%$ da amostra. Essa questão foi a segunda menos escolhida, o que representa $84,3 \%$ do total de entrevistados em todo o questionário retratando o otimismo quando se verifica a opção mais escolhida Eu não teria iniciado este negócio se eu não tivesse certeza de que seria bem sucedido. Essa escolha não surpreende o pesquisador devido ao fato de os entrevistados fazerem parte de uma comunidade com uma história repleta de lutas.

McClelland (1972) define os traços de personalidade como uma característica responsável para identificar a necessidade de realização que existe no indivíduo. Resultado similar, coincidentemente encontrado na mesma questão, indicando o menor percentual de respostas que marcaram a opção com características não empreendedoras, foi verificado nos estudos de Inácio Jr. (2002) e Kornijezuk (2004).

DOI: 10.14211regepe32140. FROTA, G. B.; BRASIL, M. V. O.; FONTENELE, R. E.

$S$. Influência das características socioeconômicas, capacidade de gestão e comportamento empreendedor no sucesso dos empreendedores participantes do programa de microcrédito do Banco Palmas. Revista de Empreendedorismo e Gestão de Pequenas Empresas, v.3, n.2, p. 42-69, 2014. 


\section{REG APr A Revista da ANEGEPE

A Tabela 6 demonstra os resultados obtidos no que diz respeito à característica propensão ao risco.

TABELA 6 - Resultados CEI Quanto à Característica Propensão ao Risco

\begin{tabular}{c|c|c|c|c|c|}
\hline CARACTERISTICAS & QUESTÃO & RCE & RCE\% & RSE & RSE\% \\
\hline Propensão ao Risco & 31 & 241 & 75,5 & 78 & 24,5 \\
Propensão ao Risco & 26 & 208 & 65,2 & 111 & 34,8 \\
Propensão ao Risco & 30 & 201 & 63,0 & 118 & 37,0 \\
\hline
\end{tabular}

Fonte: Os Autores (2012).

$\mathrm{RCE}=$ Resposta Com Característica Empreendedora

$\mathrm{RSE}=$ Resposta Sem Característica Empreendedora

$\%$ RCE = Porcentagem da amostra que marcou a sentença identificada como empreendedora

$\%$ RSE $=$ Porcentagem da amostra que marcou a sentença identificada como não empreendedora

Observa-se na característica propensão ao risco, composta por 3 questões, que todas as respostas que contêm características empreendedoras obtiveram percentual superior a $60 \%$, demonstrando que essa característica está bem evidente nos entrevistados. Isto está em consonância com o estudo de Kornijezuk (2004), no qual se pode verificar um percentual superior a 70\%. De acordo com Solomon e Fernald (1998), essa característica figura entre as principais peculiaridades do modo de agir dos empreendedores.

A questão 31, representando 75,5\%, obteve a maior frequência de respostas contendo características empreendedoras, podendo-se notar pela opção Eu realmente não sinto falta de trabalhar para alguém. Para Knight (1997), o risco existe quando o empresário tem resultados incertos, mas esses resultados podem ser previstos com certo grau de probabilidade quando existe um planejamento.

Dando sequência, a Tabela 7 demonstra os resultados obtidos quanto à característica postura estratégica:

TABELA 7 - Resultados CEI Quanto à Característica Postura Estratégica

\begin{tabular}{c|c|c|c|c|c}
\hline CARACTERISTICAS & QUESTÃO & RCE & RCE\% & RSE & RSE\% \\
\hline Postura Estratégica & 27 & 283 & 88,7 & 36 & 11,3 \\
Postura Estratégica & 12 & 227 & 71,2 & 92 & 28,8 \\
Postura Estratégica & 4 & 195 & 61,1 & 124 & 38,9 \\
Postura Estratégica & 5 & 191 & 59,9 & 128 & 40,1 \\
Postura Estratégica & 8 & 189 & 59,2 & 130 & 40,8 \\
Postura Estratégica & 20 & 175 & 54,9 & 144 & 45,1 \\
Postura Estratégica & 21 & 172 & 53,9 & 147 & 46,1 \\
Postura Estratégica & 23 & 170 & 53,3 & 149 & 46,7 \\
Postura Estratégica & 24 & 165 & 51,7 & 154 & 48,3 \\
\hline
\end{tabular}

DOI: 10.14211regepe32140. FROTA, G. B.; BRASIL, M. V. O.; FONTENELE, R. E.

S. Influência das características socioeconômicas, capacidade de gestão e comportamento empreendedor no sucesso dos empreendedores participantes do programa de microcrédito do Banco Palmas. Revista de Empreendedorismo e Gestão de Pequenas Empresas, v.3, n.2, p. 42-69, 2014. 


\section{REG A

$\begin{array}{lccccc}\text { Postura Estratégica } & 11 & 154 & 48,3 & 165 & 51,7 \\ \text { Postura Estratégica } & 1 & 123 & 38,6 & 196 & 61,4 \\ \text { Postura Estratégica } & 28 & 123 & 38,6 & 196 & 61,4 \\ \text { Postura Estratégica } & 9 & 64 & 20,1 & 255 & 79,9\end{array}$

Fonte: Os Autores (2012).

RCE = Resposta Com Característica Empreendedora

$\mathrm{RSE}=$ Resposta Sem Característica Empreendedora

$\% \mathrm{RCE}=$ Porcentagem da amostra que marcou a sentença identificada como empreendedora

$\%$ RSE = Porcentagem da amostra que marcou a sentença identificada como não empreendedora

Carland, Carland e Hoy (1992) definem a postura estratégica como um fator relacionado à capacidade do indivíduo de interagir com o ambiente de modo a estar preparado para possíveis problemas e atento às oportunidades.

Observa-se na característica postura estratégica, a maior em termos de questões a serem assinaladas, maior destaque para a questão 27 (Empréstimo é somente outra decisão de negócios), que obteve a maior frequência de respostas contendo características empreendedoras com 88,7\%. Com a menor frequência de respostas contendo características empreendedoras tem-se a questão 9: $E u$ provavelmente gasto muito tempo com este negócio.

A Tabela 8 evidencia os resultados relativos à característica propensão à inovação:

TABELA 8 - Resultados CEI Quanto à Característica Propensão à Inovação

\begin{tabular}{c|c|c|c|c|c}
\hline CARACTERÍSTICAS & QUESTÃO & RCE & RCE\% & SER & RSE\% \\
\hline Propensão à inovação & 25 & 215 & 67,4 & 104 & 32,6 \\
Propensão à inovação & 33 & 192 & 60,2 & 127 & 39,8 \\
Propensão à inovação & 19 & 184 & 57,7 & 135 & 42,3 \\
Propensão à inovação & 17 & 171 & 53,6 & 148 & 46,4 \\
Propensão à inovação & 22 & 28 & 8,8 & 291 & 91,2 \\
\hline
\end{tabular}

Fonte: Os Autores (2012).

RCE $=$ Resposta Com Característica Empreendedora

RSE = Resposta Sem Característica Empreendedora

$\% \mathrm{RCE}=$ Porcentagem da amostra que marcou a sentença identificada como empreendedora

$\%$ RSE $=$ Porcentagem da amostra que marcou a sentença identificada como não empreendedora

De acordo com Motta (1989), a propensão à invenção pressupõe que algo foi inventado, descoberto e projetado com antecedência, como resultado de um processo criativo ou da detecção de uma oportunidade (ou vice-versa).

Observa-se nessa característica que a questão 25, Eu adoro a ideia de tentar ser mais esperto que os concorrentes, obteve maior frequência de respostas com características empreendedoras, representando 67,4\%. Resultado similar

DOI: 10.14211regepe32140. FROTA, G. B.; BRASIL, M. V. O.; FONTENELE, R. E.

S. Influência das características socioeconômicas, capacidade de gestão e comportamento empreendedor no sucesso dos empreendedores participantes do programa de microcrédito do Banco Palmas. Revista de Empreendedorismo e Gestão de Pequenas Empresas, v.3, n.2, p. 42-69, 2014. 
encontra-se no estudo de Kornijezuk (2004), na questão 33, É mais importante ver possibilidades nas situações, tendo a maior frequência de respostas com características empreendedoras.

\section{Análise das equações estruturais}

A terceira parte dos resultados refere-se à utilização da técnica estatística de análise confirmatória por meio do Modelo de Equações Estruturais (SEM) com os programas Statistical Package for Social Sciences (SPSS versão 20.0) e AMOS (versão 16.0). Esses programas avaliam um conjunto de variáveis e realizam a identificação de dimensões de variabilidade comuns existentes em um conjunto de fenômenos.

Conforme descrito na metodologia, a análise de caminhos é uma técnica estatística para examinar relações causais entre duas ou mais variáveis em um sistema de equações lineares. O modelo de caminhos é o diagrama que relaciona essas variáveis, conforme demonstra a Figura 1:

DOI: 10.14211regepe32140. FROTA, G. B.; BRASIL, M. V. O.; FONTENELE, R. E. S. Influência das características socioeconômicas, capacidade de gestão e comportamento empreendedor no sucesso dos empreendedores participantes do programa de microcrédito do Banco Palmas. Revista de Empreendedorismo e Gestão de Pequenas Empresas, v.3, n.2, p. 42-69, 2014. 


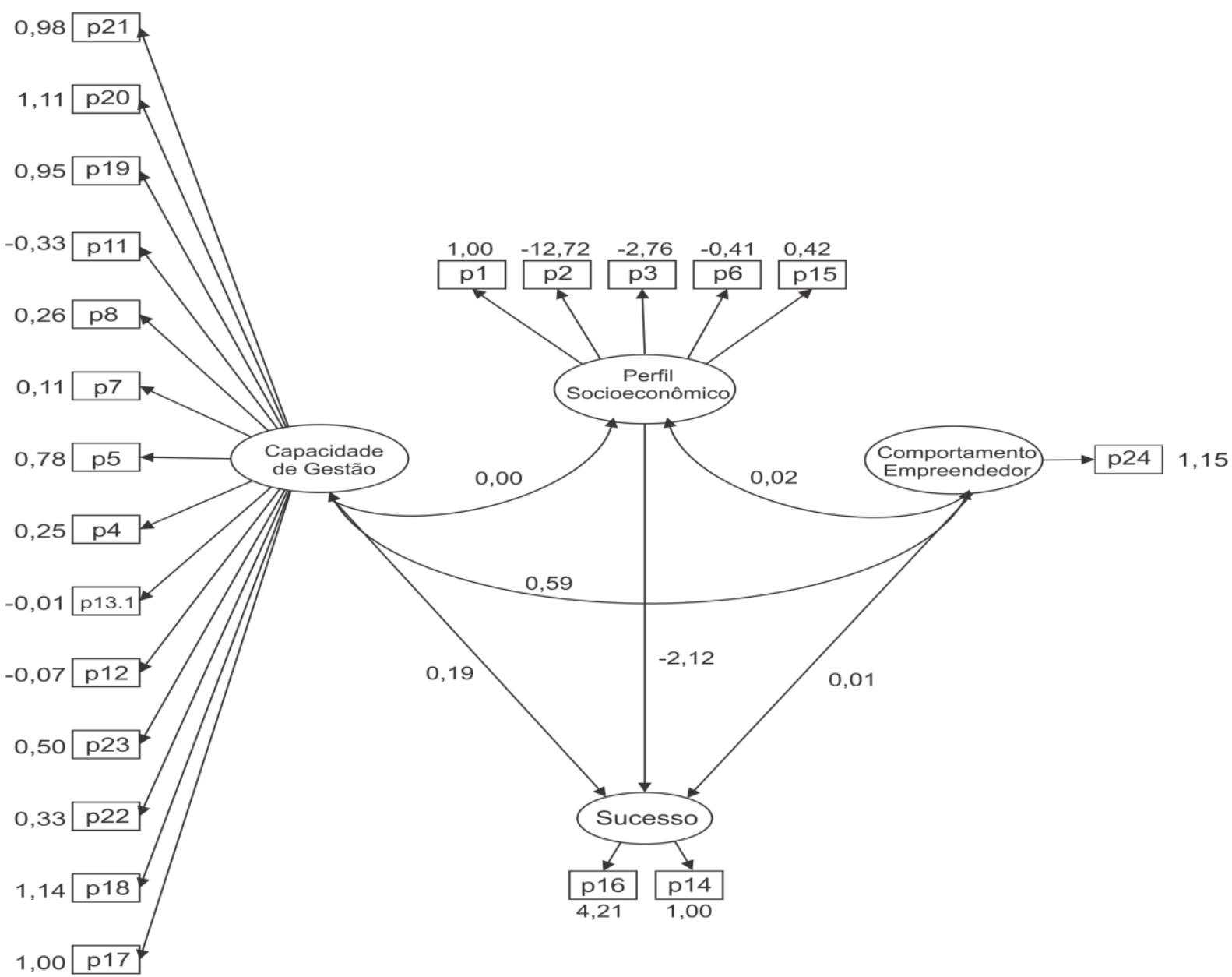

FIGURA 1- Modelo de Equações Estruturais Fonte: Os Autores (2012).

Para se entender o desenho das variáveis no diagrama de caminhos, Arblucke (1982) explica que os retângulos representam as variáveis observáveis, as elipses representam as variáveis latentes, uma seta reta com uma única ponta indica - caminho ou a relação de causa entre duas variáveis e a covariância é representada por uma seta curva com duas pontas, fornecendo uma medida não padronizada do grau no qual as variáveis se movem juntas. Essa medida é estimada tomando-se o produto dos desvios da média para cada variável em cada período.

Nas variáveis observáveis encontram-se as perguntas do questionário. Nas variáveis latentes ou constructos encontram-se: sucesso, capacidade de gestão, perfil socioeconômico e comportamento empreendedor.

DOI: 10.14211regepe32140. FROTA, G. B.; BRASIL, M. V. O.; FONTENELE, R. E. S. Influência das características socioeconômicas, capacidade de gestão e comportamento empreendedor no sucesso dos empreendedores participantes do programa de microcrédito do Banco Palmas. Revista de Empreendedorismo e Gestão de Pequenas Empresas, v.3, n.2, p. 42-69, 2014. 
Os números próximos às setas que chegam aos retângulos representam as cargas fatoriais, os que ligam as setas aos constructos representam o coeficiente da equação ou a correlação entre eles. O sinal na covariância indica o tipo de relação que as duas variáveis têm: o positivo indica que se movem juntas; o negativo, que se movem em direções opostas.

Segundo Corrar et al. (2009) o intuito das técnicas de interdependência não é o de prever o valor da variável dependente, mas sim identificar uma estrutura de relacionamentos que permita a explicação das variáveis ocorridas nas variáveis analisadas.

Pode-se constatar que a relação entre a variável capacidade de gestão e comportamento empreendedor possui correlação de 0,59. Na pesquisa, entre as relações das variáveis, esta foi a que apresentou maior correlação. Mas não poderia ser diferente, porque, conforme preceituam Carland e Carland (1996), o empreendedor se caracteriza, principalmente, pelo comportamento inovador e por empregar práticas estratégicas de gerenciamento no negócio.

Verificou-se na pesquisa que não existe correlação entre a variável perfil socioeconômico e comportamento empreendedor. Esse resultado também é diferente dos obtidos por Cooper e Dunkelberg (1984), que concluíram que a experiência profissional é um fator muito importante na intenção para a criação de novas empresas.

Pode-se constatar que não existe correlação entre a variável capacidade de gestão e perfil socioeconômico, diferentemente do resultado encontrado na pesquisa realizada por Storey (2002) junto a dirigentes de médias empresas do Reino Unido, em que constatou que as atitudes e práticas voltadas para a educação, treinamento e desenvolvimento, numa concepção mais ampla de aprendizagem, demonstram correlação com a melhoria do desempenho organizacional.

Em relação aos efeitos diretos identificados na variável latente capacidade de gestão para alcançar o sucesso empresarial pode-se afirmar possuir correlação de 0,19 . De acordo com a pesquisa de Rocha (2008), uma das principais causas do fracasso das empresas está relacionada às falhas gerenciais na condução dos negócios.

DOI: 10.14211regepe32140. FROTA, G. B.; BRASIL, M. V. O.; FONTENELE, R. E. S. Influência das características socioeconômicas, capacidade de gestão e comportamento empreendedor no sucesso dos empreendedores participantes do programa de microcrédito do Banco Palmas. Revista de Empreendedorismo e Gestão de Pequenas Empresas, v.3, n.2, p. 42-69, 2014. 
Constatou-se que não existe correlação na variável latente comportamento empreendedor e sucesso. Segundo Bouchikhi (1993), a personalidade do empreendedor não pode, sozinha, determinar o sucesso do empreendimento.

A variável latente perfil socioeconômico e sucesso teve como resultado um índice de regressão de -2,12. Diferentemente do resultado encontrado na pesquisa, Dolabela (2008) afirma que o empreendedor é produto do meio em que vive e se há na família pessoas que trabalham de forma autônoma ou que possuem seu próprio negócio, a tendência de surgir novos empreendedores é maior do que em famílias cujos membros sempre assumiram cargos de empregados. Pode-se dizer, então, que a tendência de o empreendedor ser bem-sucedido é maior nos casos em que há um ambiente de relação voltado para o empreendedorismo.

Como resultados da SEM, Hair Jr. et al. (2009) afirmam que não há um único valor que possa, sozinho, diferenciar modelos bons de modelos ruins. Nesse sentido, Hair Jr. et al. (2009) explicam que vários índices são utilizados para se avaliar:

[...] a qualidade de ajuste de um modelo e devem incluir: o Ki quadrado' DF associado, um índice de ajuste absoluto (GFI, RMSEA, SRMR), um de ajuste incremental (CFI ou TLI) um de qualidade de ajuste (GFI, CFI, TLI) e um de má qualidade de ajuste (RMSEA, SRMR). (HAIR JR. et al., 2009, p. 577).

Os resultados obtidos na pesquisa estão identificados na Tabela 9:

TABELA 9 - Resultados da SEM

\begin{tabular}{c|c|c|c|c|c|c|c|c}
\hline NPAR & CMIN & DF & P & CMIN/DF & RMR & GFI & AGFI & PGFI \\
\hline 52 & 507,034 & 224 & 0,000 & 2,264 & 0,092 & 0,883 & 0,856 & 0,717 \\
\hline NFI & RFI & IFI & TLI & CFI & PRATIO & PNFI & PCFI & NCP \\
\hline 0,628 & 0,580 & 0,751 & 0,712 & 0,745 & 0,885 & 0,556 & 0,660 & 283,034 \\
\hline FMIN & RMSEA & PCLOSE & \multicolumn{1}{c}{0} & & & \\
\hline 1,594 & 0,063 & 0,002 & & & & & & \\
\hline
\end{tabular}

Os resultados indicam Minimum Value of the Discrepancy $(\mathrm{CMIN})=507,034$ e Degrees of Freedom (DF) $=224$. O valor de $P=0,000$ indica que o modelo se ajusta perfeitamente à população.

DOI: 10.14211regepe32140. FROTA, G. B.; BRASIL, M. V. O.; FONTENELE, R. E.

S. Influência das características socioeconômicas, capacidade de gestão e comportamento empreendedor no sucesso dos empreendedores participantes do programa de microcrédito do Banco Palmas. Revista de Empreendedorismo e Gestão de Pequenas Empresas, v.3, n.2, p. 42-69, 2014. 
O índice Goodness-of-Fit Index (GFI) = 0,883 aproxima-se do aceitável que é 0,90 (HAIR JR. et al., 2009). "Os índices CFI (Comparative Fit Índex), TLI (TuckerLewis Index) variam entre 0 e 1 , com valores mais altos indicando melhor ajuste" (HAIR JR. et al., 2009, p. 584). O valor de CFI = 0,745 e do TLI = 0,712 sugerem um ajuste médio.

Segundo Byrne (2010), o índice Root Mean Square Error of Approximation (RMSEA) deve ser menor que 0,05 para que indique excelente ajuste. Porém, Hair Jr. et al. (2009, p. 569-570) indicam que esse índice "representa o quão bem um modelo se ajusta a uma população e não apenas a uma amostra [...] RMSEA está entre 0,05 e 0,08 com $95 \%$ de confiança para indicar excelente ajuste".

Arbuckle (2007, p. 592) sugere que "um excelente indicativo de ajuste para o RMSEA estaria em torno de 0,05 podendo ser utilizado até 0,08 e sugere que esse índice não deva ser utilizado se for maior que 0.1". O RMSEA $=0,063$ encontrado neste trabalho indica, segundo Byrne (2010), um bom ajuste e, segundo Hair Jr. et al. (2009) e Arbuckle (2007), um excelente ajuste.

Deve-se ressaltar também que o PCLOSE $=0,002$ encontrado neste trabalho indica que o RMSEA é quase zero e que o ajuste pode ser considerado perfeito (ARBUCKLE, 2007, p. 593).

O valor Root Mean Square Residual (RMR) "deve estar entre 0 e 1; em um modelo com excelente ajuste, esse valor será pequeno (0,05 ou menor)." (BYRNE, 2010, p. 77). "Quanto menor o RMR melhor. Um RMR $=0$ indica um ajuste perfeito". (ARBUCKLE, 2007, p. 605). Neste trabalho foi encontrado RMR $=0,092$, indicando um ajuste que pode ser considerado bom.

De uma forma geral, pode-se concluir que os resultados dos índices sugeridos por Hair Jr. et al. (2009) para avaliação do ajuste do modelo em questão indicam que o modelo apresenta um bom ajuste.

\section{Considerações finais}

O Banco Palmas tem como missão implantar programas e projetos de trabalho e geração de renda utilizando sistemas econômicos solidários na

DOI: 10.14211regepe32140. FROTA, G. B.; BRASIL, M. V. O.; FONTENELE, R. E.

S. Influência das características socioeconômicas, capacidade de gestão e comportamento empreendedor no sucesso dos empreendedores participantes do programa de microcrédito do Banco Palmas. Revista de Empreendedorismo e Gestão de Pequenas Empresas, v.3, n.2, p. 42-69, 2014. 
perspectiva de superação da pobreza urbana. Não são exigidas garantias para a concessão do crédito, a própria comunidade é quem define os parâmetros.

As iniciativas pautadas na Economia Solidária ganham cada vez mais força em torno do mundo. Um dos casos mais conhecidos é o do Grameen Bank, originado de uma experiência conduzida em 1976 pelo Professor Muhammad Yunus, catedrático do Programa de Economia Rural da Universidade de Chittagong. O projeto de crédito rural do "Grameencredit" (em Bengali) deu origem, em outubro de 1983, ao Grameen Bank ou Banco Rural. Atualmente, 90\% das ações do Grameen Bank são pertencentes às populações pobres rurais a quem ele serve e 10\% são do governo de Bangladesh (YUNUS; JOLIS, 2000).

Este estudo, enquanto instrumento de pesquisa, apresenta contribuições acadêmicas consideradas importantes para o campo de debate sobre empreendedorismo, Economia Solidária e microcrédito, tema instigante e polêmico.

Quanto aos objetivos propostos para este trabalho, considera-se que foram atingidos, cumprindo-se, de forma mais rigorosa possível, com os preceitos aplicáveis. Dessa forma, pode-se afirmar que o perfil do empreendedor está descrito da seguinte forma: a maioria dos entrevistados é do gênero feminino, com 78,4\%. Essa predominância é perfeitamente justificável devido ao fato de existirem diversos programas do Banco Palmas que estimulam a capacitação para o público feminino desenvolver atividades de fomento.

Com relação ao nível de escolaridade, identificou-se o maior percentual, com $38,2 \%$ de entrevistados que possuem apenas o Ensino Fundamental Incompleto. Seguem-se 31,67\% com o Ensino Médio Completo. Em terceiro, 14,73\% concluíram o Ensino Fundamental, sucedidos por 13,79\% que possuem o Ensino Médio Incompleto. Em outros termos: mais da metade dos entrevistados não possui o Ensino Médio Completo. Quanto ao estado civil, 70,8\% são casados, 22,6\% solteiros e $6,6 \%$ separados. Resultado similar pode ser constatado no estudo de Kornijezuk (2004).

Com relação à capacidade de gestão, pode-se afirmar que 60\% das empresas não realizaram nenhum planejamento estratégico, 64\% dos entrevistados não possuem nenhum tipo de programa que os auxiliem com o estoque e $47,8 \%$ não

DOI: 10.14211regepe32140. FROTA, G. B.; BRASIL, M. V. O.; FONTENELE, R. E.

S. Influência das características socioeconômicas, capacidade de gestão e comportamento empreendedor no sucesso dos empreendedores participantes do programa de microcrédito do Banco Palmas. Revista de Empreendedorismo e Gestão de Pequenas Empresas, v.3, n.2, p. 42-69, 2014. 
possuem nenhum tipo de controle financeiro. A ausência de planejamento estratégico compromete os anos mais difíceis da empresa, que são justamente os primeiros anos de atividade, quando existe um alto índice de encerramento do negócio.

Com relação ao perfil do empreendedor, conforme resultados obtidos no questionário de Carland e Carland (1996), identificou-se predominância de 57,8\% classificada como empreendedor, 41,9\% como microempreendedor e $1 \%$ como macroempreendedor. Resultados semelhantes foram encontrados nas pesquisas de Inácio Jr. (2002) e Kornijezuk (2004).

O sucesso foi auferido por meio de duas questões que tratam do tempo de funcionamento e faturamento da empresa. Pode-se, então, afirmar que 69,9\% dos entrevistados têm como faturamento até 2 salários mínimos, seguidos de 25,1\% com faturamento entre 2 a 5 salários mínimos. De acordo com Santos (2010), antes de as famílias recorrerem ao microcrédito, suas rendas eram abaixo de 1 salário mínimo e após a concessão do microcrédito passou a ser de até 2 salários mínimos. $\mathrm{Na}$ verdade, isso representa um crescimento de $100 \%$ e, apesar de o valor não ser expressivo, não se pode esquecer que trata-se de uma população que mora em um bairro de baixa renda.

Finalmente, no que se refere às variáveis submetidas a exame para avaliação de seu impacto no sucesso empresarial, constatou-se não existir relação entre as variáveis comportamento empreendedor e sucesso. A variável perfil socioeconômico e sucesso obteve um índice de regressão de -2,12. Apenas na variável capacidade de gestão e sucesso empresarial pode-se afirmar possuir correlação de 0,19. Rocha (2008) corrobora afirmando, em sua pesquisa, que uma das principais causas do fracasso das empresas está relacionada às falhas gerenciais na condução dos negócios.

Reconhecendo-se as limitações desta pesquisa e indicando caminhos para futuras investigações que possam trazer contribuição ao campo do empreendedorismo, sugere-se sistematizar a realização da pesquisa como alternativa de verificação da evolução da influência das variáveis perfil socioeconômico, capacidade de gestão, comportamento empreendedor e sucesso, a

DOI: 10.14211regepe32140. FROTA, G. B.; BRASIL, M. V. O.; FONTENELE, R. E. S. Influência das características socioeconômicas, capacidade de gestão e comportamento empreendedor no sucesso dos empreendedores participantes do programa de microcrédito do Banco Palmas. Revista de Empreendedorismo e Gestão de Pequenas Empresas, v.3, n.2, p. 42-69, 2014. 
fim de comparar os resultados encontrados com outras pesquisas, incluindo os impactos provenientes das variáveis exógenas para refinar este estudo.

\section{Referências:}

ARBUCKLE, J. AMOS 16.0 User's Guide. Chicago: Amos Development Corporation, 1995, 656 p.

ARRUDA, M. Redes, educação e economia solidária: novas formas de pensar a educação de jovens e adultos. In: KRUPPA, S. (Org.). Economia solidária e educação de jovens e adultos. Brasília: INEP, 2005.

ASMOCONP/Banco Palmas. 2004. Avaliação de Impactos e de Imagem: Banco Palmas. Fortaleza: Arte Visual, 2008.

BERTUCCI, A.; SILVA, R. 20 anos de Economia Popular Solidária. Brasília: Venâncio III, 2003.

BOUCHIKHI, H. A construtivist framework for understanding entrepreneurship performance. Organization Studies, v. 14, n. 4, p. 549-571, jul. 1993.

BYRNE, B. Structural equation modeling with AMOS: basic concepts, applications, and Programming. New York: Routledge, 2010.

CARLAND, J. W. ; CARLAND, J. C. ; HOY, F. S. ; BABSON COLLEGE; CENTER FOR ENTREPRENEURIAL STUDIES. An entrepreneurship index: an empirical validation. In: Frontiers of Entrepreneurship Research, 12., 1992, Babson. Conference..., Babson: Babson College, 1992, 606 p.

CARLAND, J.; CARLAND, J. The Theoretical Bases and Dimensionality of the Carland Entrepreneurship Index. In: Proceedings of the rise conference. University of Jyväskylä, Finlândia, 1996, p. 1-24.

COOPER, A.; DUNKELBERG, W. Entrepreneurship and paths to business ownership. Paper 846, Krannert Graduate School of Management, Perdue University, 1984.

COOPER, D. R.; SCHINDLER, P. S. Métodos de pesquisa em administração. 7. ed. Porto Alegre: Bookman, 2003.

CORRAR, L. J. et al. Análise multivariada para os cursos de administração, ciências contábeis e economia. São Paulo: Atlas, 2009.

DOI: 10.14211regepe32140. FROTA, G. B.; BRASIL, M. V. O.; FONTENELE, R. E. S. Influência das características socioeconômicas, capacidade de gestão e comportamento empreendedor no sucesso dos empreendedores participantes do programa de microcrédito do Banco Palmas. Revista de Empreendedorismo e Gestão de Pequenas Empresas, v.3, n.2, p. 42-69, 2014. 
CROMIE, S. Assessing entrepreneurial inclinations: Some approaches and empirical evidence. European Journal of Work and Organizational Psychology, v. 9, n. 1, p. 7-30, 2000.

DOLABELA, F. Oficina do Empreendedor. Rio de Janeiro: Sextante, 2008.

FERREIRA, J. Potencial Empreendedor e Liderança Criativa: um estudo com varejistas de materiais de construção da cidade de Curitiba. 2005. Dissertação (Mestrado em Administração) - Pontifícia Universidade Católica do Paraná, Paraná, 2005.

GONÇALVES, W. O marco jurídico da autogestão e economia solidária (relatório final do convênio MTE/ IPEA/ ANPEC - 01/2003). Brasília: MTE, IPEA, ANPEC, 2005.

HAIR JR., J. et al. Análise Multivariada de Dados. 6. ed. São Paulo: Bookman, 2009.

INÁCIO JR., E. Empreendedorismo e Liderança Criativa: um estudo com os proprietários gerentes de empresas incubadas no Estado do Paraná. 2002, 136 f. Dissertação (Mestrado em Administração) - Universidade Federal de Maringá, Maringá, 2002.

INÁCIO JR., E.; GIMENEZ, F. Potencial empreendedor: um instrumento para mensuração. Revista de Negócios, v. 9, n. 2, p. 107-116, 2004.

JAYO, M., CALDAS, E. L. Habitando o inabitável: geração de renda e desenvolvimento local no conjunto Palmeiras. Administração Pública e Gestão Social, São Paulo, v. 6, n. 1, p. 51-55, jan./mar. 2014.

$\mathrm{KNIGHT}$, G. A. Cross-cultural reliability and validity of a scale to measure firm entrepreneurial orientation. Journal of Business Venturing, v. 12, n. 3, p. 213-225, maio 1997.

KORNIJEZUK, F. Características empreendedoras de pequenos empresários de Brasília. 2004, 129 f. Dissertação (Mestrado em Administração) - Faculdade de Economia, Administração, Contabilidade e Ciência da Informação e Documentação - FACE, Programa de Pós-Graduação em Administração - PPGA, Universidade de Brasília, Brasília, 2004.

LISBOA, A. A emergência das redes de economia popular no Brasil. In: DAL RI, N. M.(Org.). Economia solidária: o desafio da democratização das relações de trabalho. São Paulo: Arte e Ciência, 1999. p. 43-53.

MALHOTRA, N. Pesquisa de Marketing: uma orientação aplicada. 4. ed. São Paulo: Bookman, 2006.

DOI: 10.14211regepe32140. FROTA, G. B.; BRASIL, M. V. O.; FONTENELE, R. E.

S. Influência das características socioeconômicas, capacidade de gestão e comportamento empreendedor no sucesso dos empreendedores participantes do programa de microcrédito do Banco Palmas. Revista de Empreendedorismo e Gestão de Pequenas Empresas, v.3, n.2, p. 42-69, 2014. 
MANCE, E. Redes de economia solidária. Salvador: Cadernos da Fundação Luís Eduardo Magalhaes, Cadernos FLEM, n. 5, 2003.

MCCLELLAND, D. A sociedade competitiva: realização e progresso social. Rio de Janeiro: Expressão e Cultura, 1972.

MOTTA, P. R. Gerência de ideias novas: como despertar a criatividade e vencer a impotência do desejo motivacional? Revista de Administração Pública, Rio de Janeiro, v. 23, n. 4, p. 71-86, 1989.

PRATHER, C. W. Keeping innovation alive after consultants leave. Research Technology Management, v. 43, n. 5, p.17-22, 2000.

ROCHA, M. Microempresas no Brasil: análise do período de 1984 a 2005. Revista Eletrônica de Administração, v. 14, n 2, 2008. Disponível em: <http://www.read.ea.ufrgs.br/edicoes/busca.php>. Acesso em: 23 nov. 2010.

SILVA JUNIOR, J. Gestão, Fato Associativo \& Economia Solidária: a experiência da ASMOCONP/Banco Palmas. 2004. Dissertação (Mestrado em Administração)Escola de Administração da Universidade Federal da Bahia, Salvador, Bahia, Brasil, 2004.

STOREY, D. J. Education, training and development policies and practices in medium-sized companies in the UK: Do they really influence firm performance? Omega, v. 30, n. 4, p. 249-264, 2002.

SINGER, P. Introdução à Economia Solidária. São Paulo: Perseu Abramo, 2002.

SINGER, P.; SOUZA, A. de. (Orgs.). A economia solidária no Brasil: a autogestão como resposta ao desemprego. São Paulo: Contexto, 2000.

SILVA Jr., J. T. Avaliação de impactos e de imagem: Banco Palmas - 10 anos. Disponível

http://www.complementarycurrency.org/ccLibrary/Rapport_Jeova_Evaluation_BP.pdf Acesso em: 12 ago. 2014.

SOLOMON, G.; FERNALD, L. Value profiles of male and female entrepreneurs. International Journal of Small Business, v. 6, n. 3, p. 24-33, 1998.

YUNUS, M.; JOLIS, A. O Banqueiro dos Pobres. São Paulo: Ática, 2000.

ZELLER, R. A.; CARMINES, E. G. Measurement in the Social Sciences: The Link between Theory and Data. New York: Cambridge University Press, 1980.

Artigo recebido em: 12/05/2014. Artigo aprovado em: 14/08/2014

DOI: 10.14211regepe32140. FROTA, G. B.; BRASIL, M. V. O.; FONTENELE, R. E.

S. Influência das características socioeconômicas, capacidade de gestão e comportamento empreendedor no sucesso dos empreendedores participantes do programa de microcrédito do Banco Palmas. Revista de Empreendedorismo e Gestão de Pequenas Empresas, v.3, n.2, p. 42-69, 2014. 